\title{
Seasonal cycle of hydrography in the Bab el Mandab region, southern Red Sea
}

\author{
M A Al SaAfani and S S C Shenoi \\ Physical Oceanography Division, National Institute of Oceanography, Goa 403 004, India.
}

The seasonal cycle of temperature - salinity variations in the Bab el Mandab region (southern Red Sea) is described using CTD data collected during four cruises spread over the period May 1995August 1997. A two layer system exists during early summer, winter and spring while a three layer system exists during summer. During summer, a large amount of the Gulf of Aden water intrudes into the Bab el Mandab region; up to the northern limit $\left(14.5^{\circ} \mathrm{N}\right)$. The quantity of Red Sea water that flows into the Gulf of Aden is maximum during the winter and minimum during the summer.

\section{Introduction}

The Red Sea has a typical geometry where the depth varies from $3000 \mathrm{~m}$ to $160 \mathrm{~m}$. The shallow sill where the depth is about $160 \mathrm{~m}\left(13^{\circ} 44^{\prime} \mathrm{N}\right)$ is considered as the real separation of the Red Sea from the Gulf of Aden. The southern end of the Red Sea is narrow $(\sim 26 \mathrm{~km})$ and merges with the Gulf of Aden through the Strait of Bab el Mandab. The Myyun (Perim) Island divides the Bab el Mandab into two channels (figure 1). The small strait on the eastern side is about $4 \mathrm{~km}$ wide and less than $26 \mathrm{~m}$ deep, whereas the large strait on the west of Myyun is about $18 \mathrm{~km}$ wide and $300 \mathrm{~m}$ deep. The Strait of Bab el Mandab connects the Red Sea with the Gulf of Aden in the south.

Consistent northwesterly winds blow over the Red Sea except for the reversal in the south, during the northern winter (figure 2). The Red Sea receives a negligible amount of fresh water since no rivers or rivulets debauch into it. The Gulf of Aden (GA) is the only source for water for the Red Sea except for the small amount of water exchanged through the Suez canal. The amount of water received through precipitation also is negligible. Due to excess evaporation the Red Sea behaves as a typical concentration basin. The estimates of average evaporation varies from 175 to $230 \mathrm{~cm} \mathrm{yr}^{-1}$ (Bunkar et al 1982; Tragou et al 1999; Sofianos et al 2002).

During winter (October to February), the southern region of the Red Sea, the Bab el Mandab region, experiences a two layer flow system typical of the inverse estuarine circulation where a fresh inflow prevails over a hypersaline outflow. During this period, the upper layer $(\sim 80 \mathrm{~m}$ deep $)$ experiences an inflow while the deeper layer (below $80 \mathrm{~m}$ ) experiences an outflow (Maillard and Soliman 1986; Murray and Johns 1997; hereafter MJ). The incoming surface water from GA has an average salinity of $36.5 \mathrm{psu}$ and an average temperature of $26-28^{\circ} \mathrm{C}$ while the lower layer outflow of the Red Sea deep water has an average salinity of $40.5 \mathrm{psu}$ and an average temperature of $21.5^{\circ} \mathrm{C}$. In summer (June to September) a three layer circulation system develops in the Bab el Mandab region (Maillard and Soliman 1986); a warm outflow at the top, a cooler inflow in the middle and a saline outflow at the bottom. The warm saline outflow $\left(30.5^{\circ} \mathrm{C}, 37.0 \mathrm{psu}\right)$ confines to the top $20 \mathrm{~m}$ layer. The cooler inflow is fresher $\left(19.0^{\circ} \mathrm{C}, 36.0 \mathrm{psu}\right)$ and is from GA. The deeper high saline water has its origin in the northern Red Sea (Maillard 1974; Murray et al 1984; Cember 1988).

Keywords. Hydrography; Gulf of Aden; Red Sea water; circulation. 


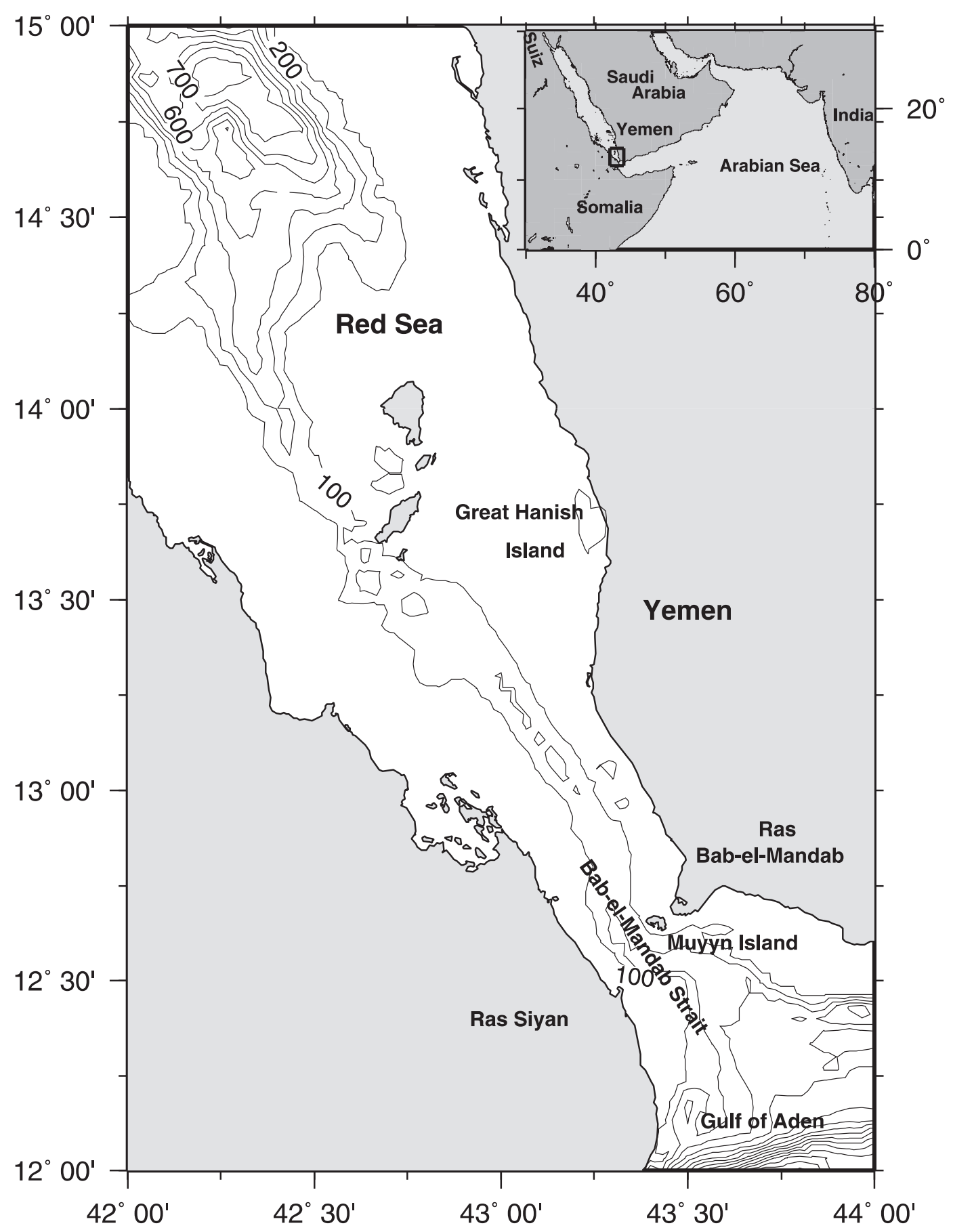

Figure 1. Area of study. The southern part of the Red Sea extending from Hanish Island to Strait of Bab el Mandab is refered as Bab el Mandab region. Bathemetric contours are also shown.

Thompson (1939) and Patzert (1972) have related the circulation and exchange of the water masses in the Red Sea to monsoonal winds while Neumann and McGill (1962) and Tragou et al (1999) related the same to buoyancy forcing. The relative importance of each of them is still debatable. Wind-induced upwelling in the GA and the reversal in the winds over the Red Sea are believed to be the reasons for the development of the threelayer exchange system during summer at the strait (Patzert 1974; Smeed 1997, 2000).
Most of the inferences described above comes from observations that are widely scattered in time. Till recently, no data set was available to describe the complete seasonal cycle. The most complete data, in space and time, were collected in 1995-1997 (MJ). The data set includes the temperature-salinity profiles at stations spread over the southern Red Sea, the current meter moorings and the current measurements using acoustic doppler current profiler. Using this data, MJ described the seasonal exchange through the 

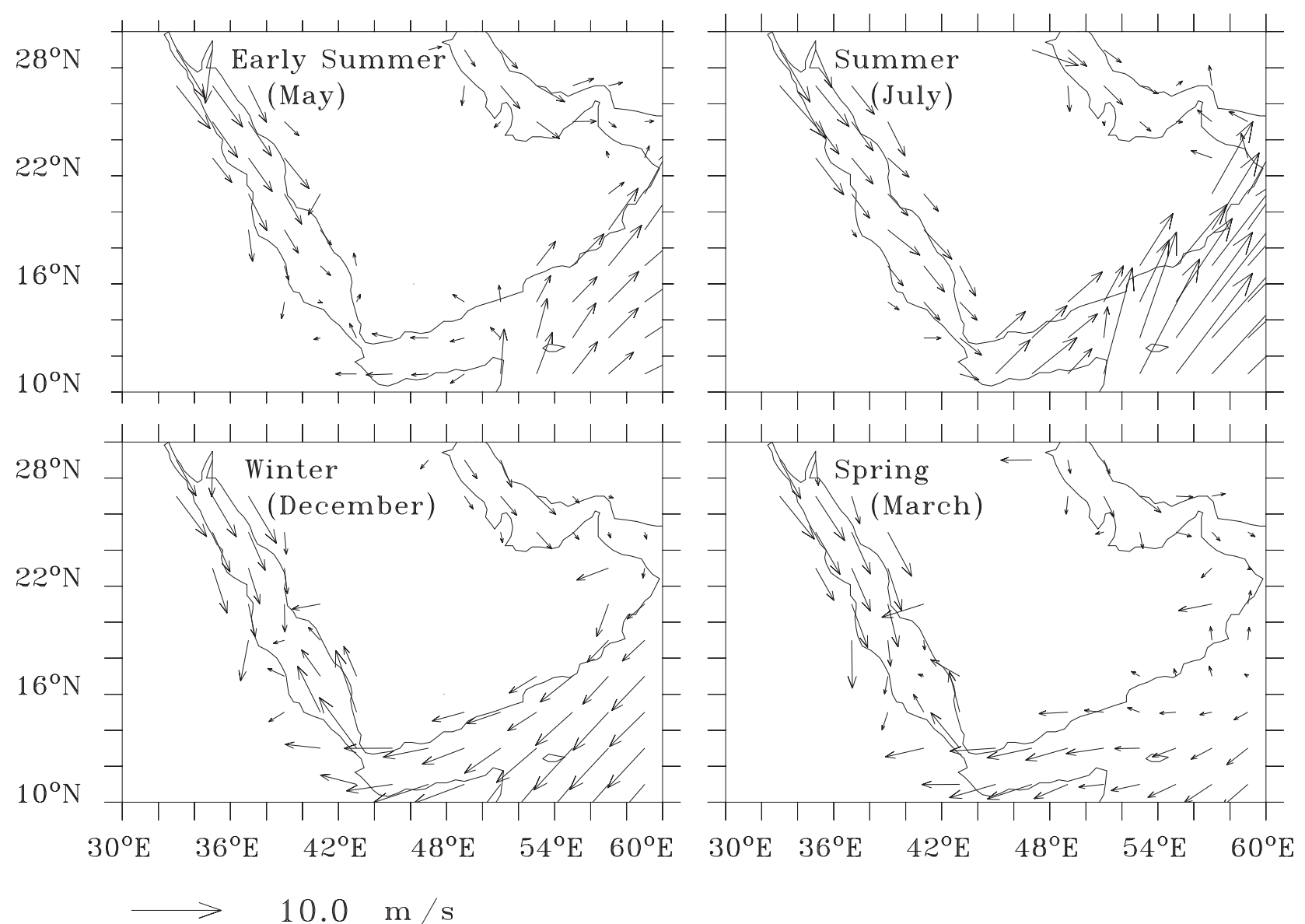

Figure 2. Winds over the Red Sea during (a) early summer, (b) summer, (c) winter, and (d) spring based on COADS climatology.

Table 1. The details of the four cruises conducted to collect the hydrographic data from the Bab el Mandab region during 1995-1997. A Sea Bird CTD model SBE 9 plus was used for the recording of temperature-salinity profiles.

\begin{tabular}{cllcc}
\hline $\begin{array}{c}\text { Cruise } \\
\text { No. }\end{array}$ & \multicolumn{1}{c}{ Period } & \multicolumn{1}{c}{ Ship } & $\begin{array}{c}\text { No. of } \\
\text { sections }\end{array}$ & $\begin{array}{c}\text { No. of } \\
\text { stations }\end{array}$ \\
\hline 1 & 26th May-4th June 1995 & MV Argo Service & 7 & 52 \\
2 & 16th March-18th April 1996 & MV Scorpio del Gulfo & 3 & 43 \\
3 & 14th November-13th December 1996 & MV Big Orange IV & 4 & 42 \\
4 & 20th July-8th August 1997 & MV Eritreedom & 2 & 21 \\
\hline
\end{tabular}

Bab el Mandab Strait and Sofianos et al (2002) estimated the heat and freshwater budgets in the Red Sea. Both studies concentrated on the time variability of the processes and made use of the time series measurements obtained through the moored instrumentation. In this study, we make use of the temperature-salinity profiles collected during the same period through four hydrographic cruises (table 1) to describe the seasonal cycle of hydrography in the Bab el Mandab region and compare them with previous studies. Section 2 presents the seasonal cycle of hydrography in the Bab el Mandab region and section 3 provides the discussion and conclusions.

\section{Seasonal cycle of hydrography}

The data were collected during four cruises representing the seasons early summer, summer, winter and spring. In the following discussions we describe the seasonal cycle based on these observations. Figure 3 shows the distribution of hydrographic stations during each cruise.

\subsection{Early summer}

During early summer (26th May-4th June 1995) the vertical structure of hydrography (figure $4 \mathrm{a}-\mathrm{c})$ shows a surface mixed layer $(\sim 40 \mathrm{~m})$ of 


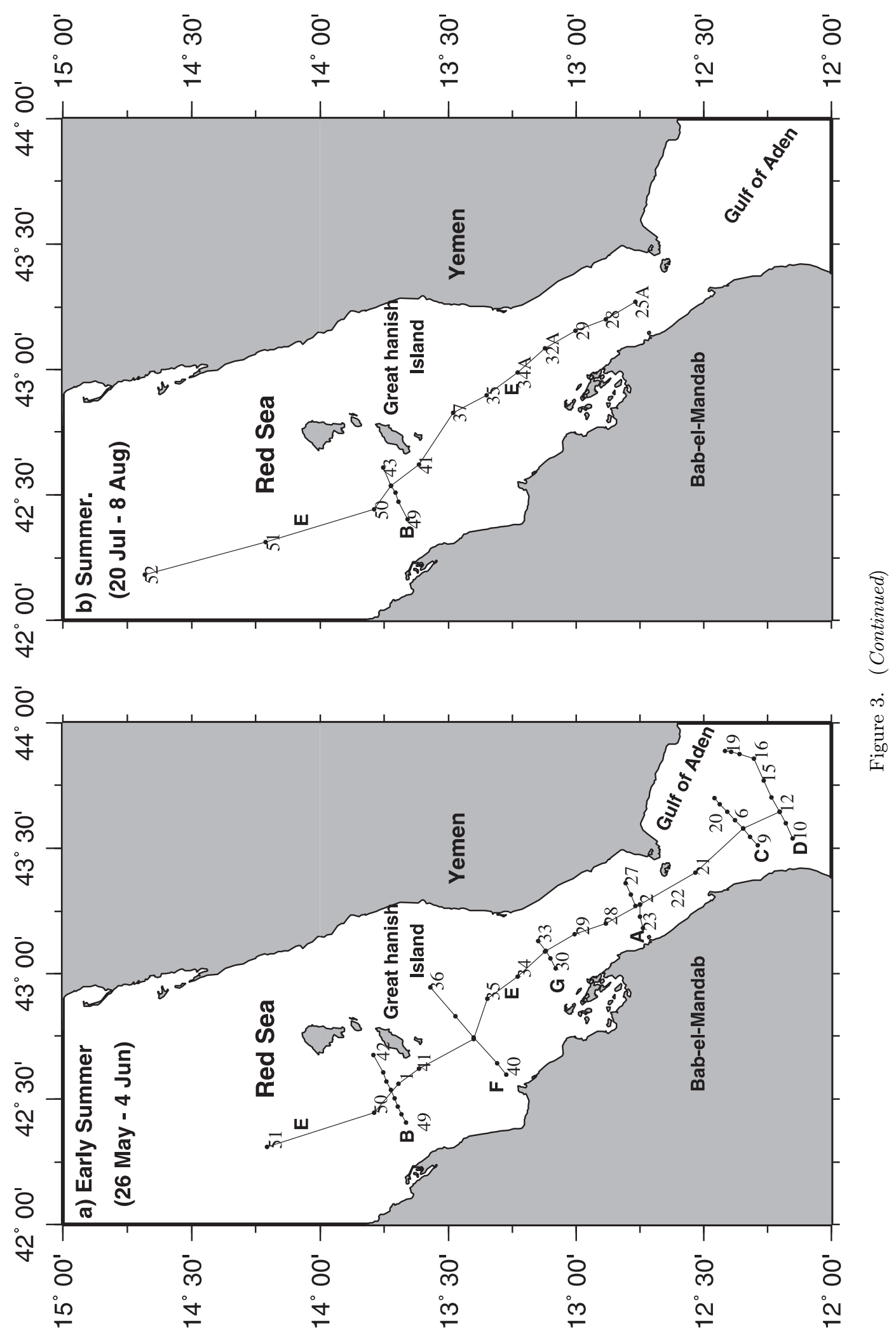


Hydrography in the Bab el Mandab region

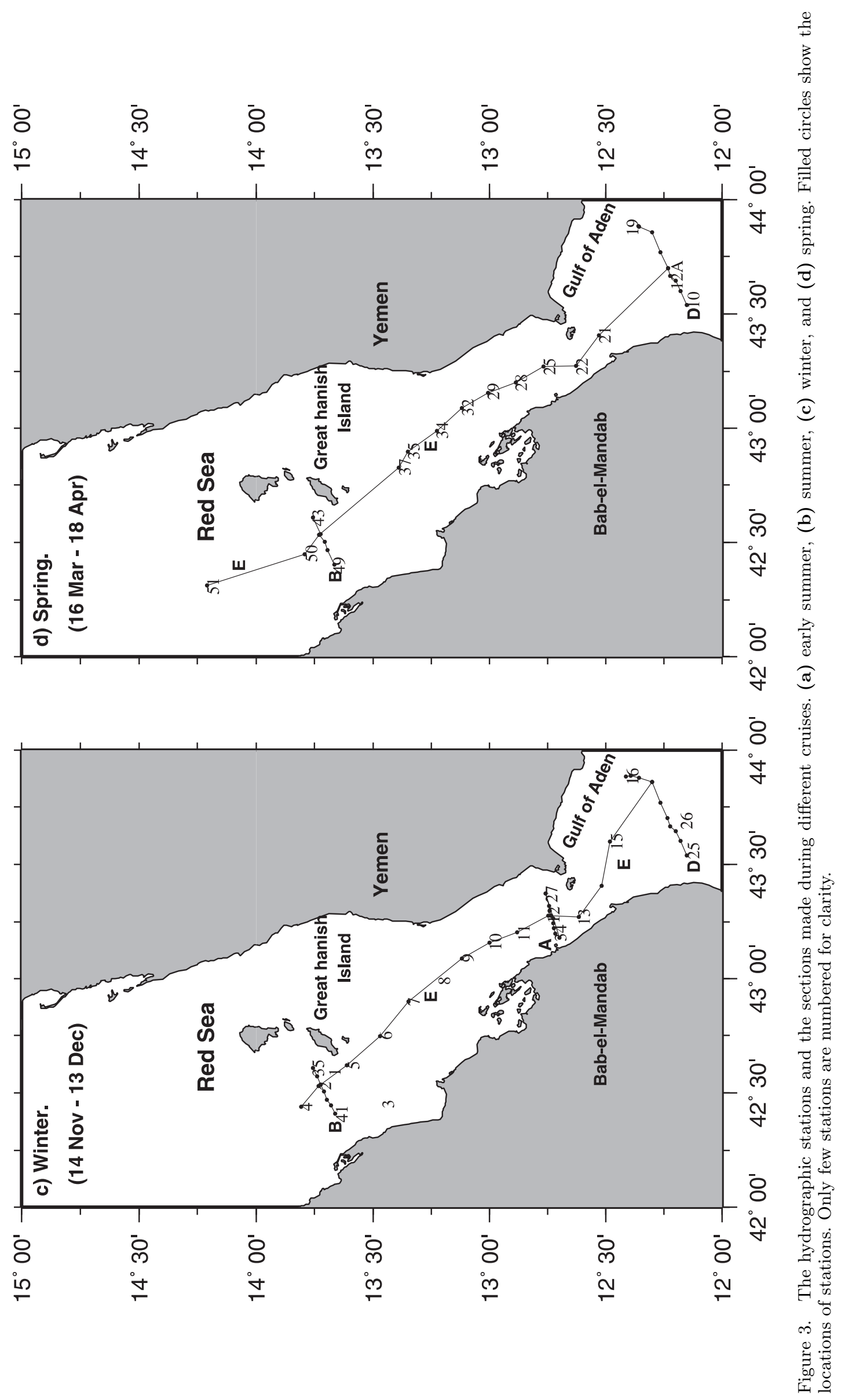


temperature $30-30.5^{\circ} \mathrm{C}$ and salinity $36-36.5 \mathrm{psu}$. The isotherms, isohalines, and isopycnals bend upward at the sill where the depth reduces sharply (stations 38, 41, 1, and 45). The thermocline deepens to about $140 \mathrm{~m}$ along the section except at the sill where it shallows to $80 \mathrm{~m}$. The Red Sea Water (RSW) having a temperature of $22^{\circ} \mathrm{C}$ and salinity $40-40.5 \mathrm{psu}$ occupies the area below the thermocline. The Bab el Mandab region acts as the transition region for the RSW outflow in which its properties change between the sill (temperature $21.0-22.0^{\circ} \mathrm{C}$, salinity $40.0-41.0 \mathrm{psu}$ ) and the strait (temperature $22.0-23.0^{\circ} \mathrm{C}$, salinity $40.0-40.5 \mathrm{psu}$ ) due to mixing with the water in the layer above (figure $4 \mathrm{a}$ and $\mathrm{b}$ ). At the southern end of this section, in the GA, at around $150 \mathrm{~m}$ to $250 \mathrm{~m}$ the temperature ranges between 16 and $18^{\circ} \mathrm{C}$ while the salinity is $\sim 36.0 \mathrm{psu}$. This is typical of the Gulf of Aden Water (GAW). There is evidence for a three layer temperature-salinity structure at these stations which lie in the Gulf of Aden, but not in the stations in the Bab el Mandab. The situation was similar during mid June 1958 (Neumann and McGill 1962). Maillard and Soliman (1986) noted the entry of cooler fresher water into the RS in the intermediate layer during late June though it did not penetrate up to the sill.

There is hardly any variation in the horizontal distribution of temperature at surface $(5 \mathrm{~m}$ depth) except for a small pocket of cold water on the western side near $13.4^{\circ} \mathrm{N}$ (figure $4 \mathrm{~d}$ ). The water is saltier than the surroundings in the cold water pocket (figure 4e). Except for the high salinity in the north $(\sim 37.5 \mathrm{psu})$ there is no drastic variation in the horizontal distribution of salinity either (figure 4e). Contrary to the temperature distribution at the surface, the temperature distribution at $100 \mathrm{~m}$ (figure 4f) shows cooler temperatures in the north and south $\left(22-23^{\circ} \mathrm{C}\right)$ and warmer temperature in the central part $\left(24-25^{\circ} \mathrm{C}\right)$. However, the salinity (figure $4 \mathrm{~g}$ ) decreases gradually from north to south ( $>40 \mathrm{psu}$ to $35.5 \mathrm{psu}$ ). At $150 \mathrm{~m}$ level the temperature is uniform over the basin except in the GA where sharp gradients are present (figure $4 \mathrm{~h}$ ). Salinity also shows sharp gradients in the GA associated with the temperature gradients (figure $4 \mathrm{~g}$ and $\mathrm{i}$ ) due to the arrival of RSW.

\subsection{Summer}

In summer (July - August) the surface mixed layer $\left(31-32^{\circ} \mathrm{C}, 37-37.5 \mathrm{psu}\right)$ extends to $\sim 40 \mathrm{~m}$ (figure 5 $\mathrm{a}-\mathrm{c})$. Near the sill, the mixed layer shallows to about $20 \mathrm{~m}$. A well-defined thermocline extends up to $80 \mathrm{~m}$ where temperature decreases to $19^{\circ} \mathrm{C}$ and salinity decreases to $36.0 \mathrm{psu}$. The intermediate layer has temperature ranging between 16 and $18^{\circ} \mathrm{C}$, and salinity between 35.5 and $36.0 \mathrm{psu}$. This intermediate layer extends from 50 to $180 \mathrm{~m}$ in the southern part of the section but its thickness reduces towards north. The $\mathrm{RSW}$ that enters the region through the sill (temperature $21-22^{\circ} \mathrm{C}$ and salinity $40-40.5 \mathrm{psu}$ ) occupies the region below $180 \mathrm{~m}$.

The horizontal distributions of surface temperature and salinity show no variations except for a warmer fresher patch on the western side of the sill (figure 5d and e). However, the distributions of temperature and salinity at $100 \mathrm{~m}$, and $150 \mathrm{~m}$ depths have different patterns than those at the surface. At $100 \mathrm{~m}$ (figure $5 \mathrm{f}$ and $\mathrm{g}$ ) the temperature and salinity indicate the spread of cooler-fresher GAW up to the sill $\left(13.75^{\circ} \mathrm{N}\right)$. At $150 \mathrm{~m}$ (figure $5 \mathrm{~h}$ and i) the properties indicate the presence of the RSW $\left(22^{\circ} \mathrm{C}, 40.0 \mathrm{psu}\right)$ in the north and GAW in the south.

The temperature-salinity structure suggests a three layer system with significant intrusion of GAW at the intermediate levels (150-250 m). From the salinity distribution near the bottom it appears that the volume of bottom water (RSW), sliding down towards south has diminished considerably (figure 5) than that during early summer. The high salinity RSW which plunges down at the sill and slides towards south gets diluted considerably due to mixing with the low salinity water from the GA. The $40 \mathrm{psu}$ contour, which covered the entire region during the other three seasons, had almost disappeared at immediate south of the sill. The thick intermediate layer (extending between 50 and $175 \mathrm{~m}$ depths) restricted the upper layer to a thin band of warm-saline water. The temperaturesalinity structure is similar to the three layer system described by Maillard and Soliman (1986) based on the data obtained during SeptemberOctober 1982. The reduced deep outflow presumably results from the cessation of deep water formation in the northern Red Sea in late spring. While the surface flow, appears to be resulting from the seasonal reversal of the winds over the southern Red Sea. The vertical section of temperature and salinity (figure not shown) along section B indicates deepening of isotherms on the western side. This is typical of the downwelling in response to the NW winds. It is possible that the pocket of warm fresh water found on the western side (figure $5 \mathrm{~d}$ and e) near the sill is a manifestation of downwelling. The model studies of Sofianos and Johns (2003) also indicate wind induced upwelling along the eastern side and downwelling on the western side of the southern Red Sea. Sofianos and Johns (2003) describe a gyre situated between $14^{\circ} \mathrm{N}$ and $16^{\circ} \mathrm{N}$ on the western side. It rotates cyclonic during summer and anti-cyclonic during winter. However, it is not clear whether the warm (cold) 
water pocket noticed in early summer (summer) is influenced by the mesoscale gyre described by Sofianos and Johns (2003).

\subsection{Winter}

The two layer structure appears to have established again with a surface layer and a deeper layer during November-December. The surface layer temperature and salinity varies between 27 and $28^{\circ} \mathrm{C}$ and 36.5 and $37.0 \mathrm{psu}$ (figure $6 \mathrm{a}-\mathrm{c}$ ) which increases gradually from south to north. However, the thickness of this layer decreases towards north reducing up to $80 \mathrm{~m}$ near the sill (figure $6 \mathrm{a}-\mathrm{c}$ ). Compared to summer, the thermocline is weak. Below the upper layer, the RSW which plunges down from the sill flows towards south has temperature and salinity ranging between 22 and $23^{\circ} \mathrm{C}$ and 39.0 and $40.5 \mathrm{psu}$ respectively. In the GA, this water slides below GAW which has salinity $\sim 36.0$ psu and temperature $\sim 17^{\circ} \mathrm{C}$.

There is very little variation in the horizontal distribution of temperature and salinity at the surface except for the lower temperature (figure $6 \mathrm{~d}$ and e) in the northern side of the sill. At $100 \mathrm{~m}$ depth the picture is different where temperature decreases and salinity increases gradually towards north (figure $6 \mathrm{f}$ and $\mathrm{g}$ ). At $150 \mathrm{~m}$ level (figure $6 \mathrm{~h}$ and $\mathrm{i}$ ), the water north of the strait represents the RSW $\left(22^{\circ} \mathrm{C}, 40-40.5 \mathrm{psu}\right)$, while the water south of the strait represents GAW. More GAW can be found on the eastern side than on the western side. It appears that RSW that flows into the GA at depths around 125-300 m pushes the GAW towards east.

A similar two layer structure was found by Siedler (1968) during winter. MJ notes that the winter regime that begins in mid-September 1995 develops fully in early November and continues till March 1996. As per their observations, the maximum outflow of RSW occurred in mid-February $(\sim 0.7 \mathrm{~Sv})$.

\subsection{Spring}

During spring (March-April) the winds though weakened still followed the winter pattern; blowing from SE over the southern Red Sea. The hydrographic structure during this season also represents a two layer structure with a surface layer of temperature $27-28^{\circ} \mathrm{C}$ and salinity $36.5 \mathrm{psu}$ extending to a depth of $\sim 50 \mathrm{~m}$ (figure $7 \mathrm{a}-\mathrm{c}$ ). Similar to winter, the thermocline was weak. The RSW $\left(22^{\circ} \mathrm{C}\right.$, $40.0 \mathrm{psu}$ ) occupies the bottom layer. A comparison of temperature and salinity structures with those for winter indicates that the strength of the outflow of RSW has reduced during this season (figures 6 and 7). Similarly, the upper layer temperature and salinity are lower than those during the winter.
The horizontal distribution of temperature and salinity at the surface showed warm-saline water in the north (figure $7 \mathrm{~d}$ and e). At 100 and $150 \mathrm{~m}$ (figure $7 \mathrm{f}-\mathrm{i}$ ) the temperature showed a gradual increase till the strait at Bab el Mandab and then a decrease due to the mixing of RSW with GAW. The distribution of salinity at these levels showed a gradual decrease as it approached the GA. South of the strait of Bab el Mandab the presence of GAW influenced the hydrographic structure by diluting the RSW (figure $7 \mathrm{f}-\mathrm{i}$ ). During this season also, the outflow of RSW occurred, mainly, along the western side (figure $7 \mathrm{~h}$ and i) of GA.

No other hydrographic observations are available for this season prior to these observations. The direct measurements of currents (MJ) during March - April 1996 agree with the two layer structure observed here.

\section{Discussion and Conclusions}

The present study describes the hydrographic structure of the Bab el Mandab region observed during four seasons - namely, early summer, summer, winter and spring using a consistent data set. The data for spring became available for the first time. Previous studies mostly depended on the scattered data sets. The present study as well as the previous studies suggest the presence of a consistent seasonal cycle in the Bab el Mandab region. Based on the present and past studies (Neumann and McGill 1962; Maillard and Soliman 1986 and MJ) we confirm the existence of a two layer system in the Bab el Mandab region even during early June (early summer). The transition to three layer structure occurs sometime towards the end of June. The three layer system first formed in the strait of Bab el Mandab, gradually progresses towards north to reach the sill $\left(14^{\circ} \mathrm{N}\right)$ in July. It progresses further north up to $18^{\circ} \mathrm{N}$ in October as noted by Maillard and Soliman (1986). But the results of MJ did not show a three layer system after mid-September in the strait of Bab el Mandab. The inconsistency in the two observations must be due to the interannual variability in the timing of formation and cessation of the three layer system in the Bab el Mandab region. More data are required to study the inter-annual variability. Similarly, the data are insufficient to describe the upwelling (downwelling) along the east (west) coast.

Consistent with the direct observations of currents (MJ), the hydrographic observations also suggest the existence of a two layer winter regime circulation almost throughout the year (early summer, winter and spring) except during summer. From the thickness of RSW layer (figures 4-7), it is evident that the outflow of RSW was minimum during summer and maximum during winter. 


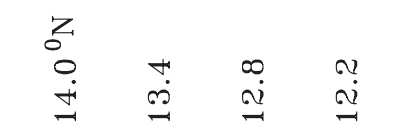
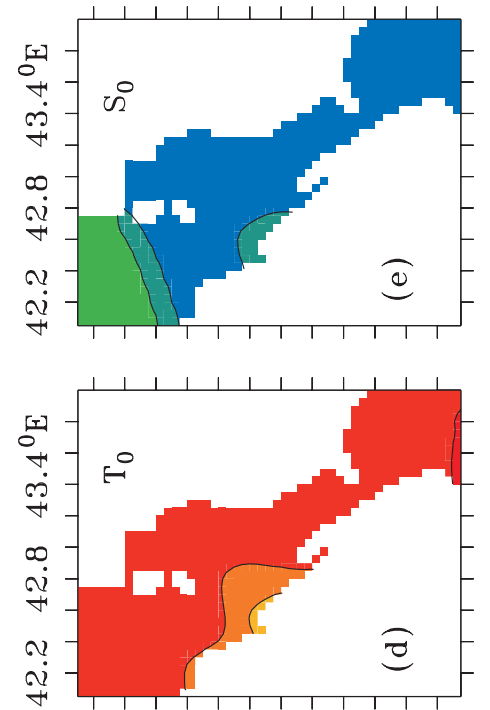

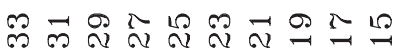

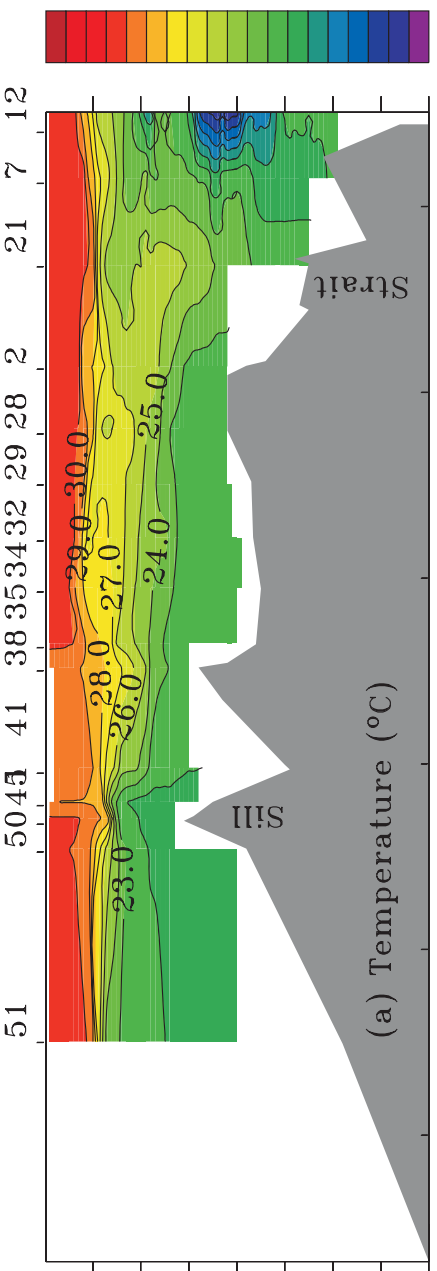

i் $\stackrel{\circ}{\circ} \stackrel{\circ}{\circ}$

I্
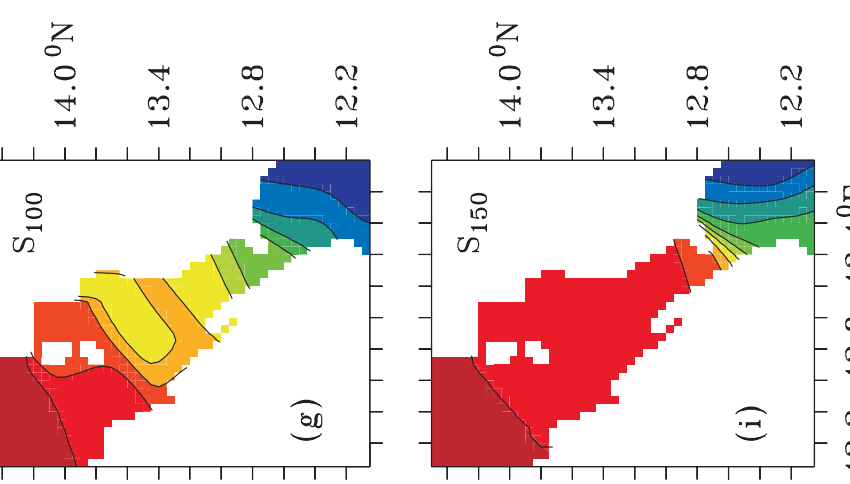

$\stackrel{g}{F}$
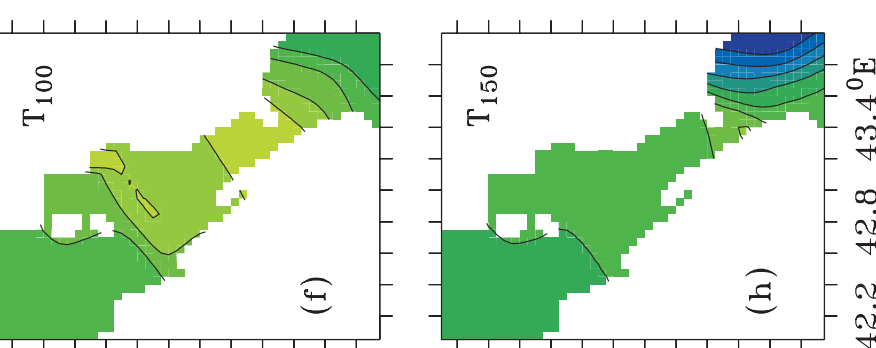

○
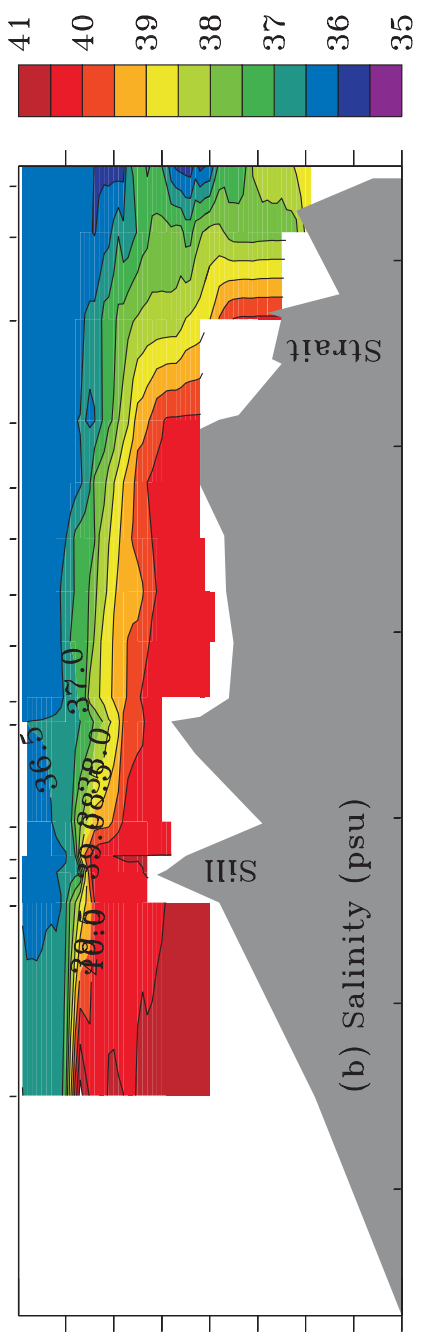

$\stackrel{\circ}{\circ} \stackrel{\circ}{\circ}$

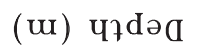
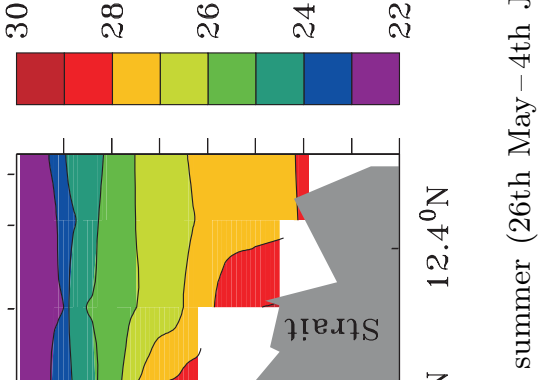

궁요

\#. बृ

$\stackrel{v}{-}$

छั

है

$\rightarrow \overline{0}$

范

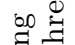

范

ลิ

$\stackrel{8}{\square}$

S.

$\otimes$
0
0

四

红究

\begin{tabular}{lll}
$z$ & 0 \\
0 & 0 & 0 \\
0 & 0 & 0 \\
\hline
\end{tabular}

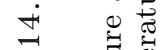

苟

政

虫

글

क.

总

+ن

․ㅗㅇ 
Hydrography in the Bab el Mandab region
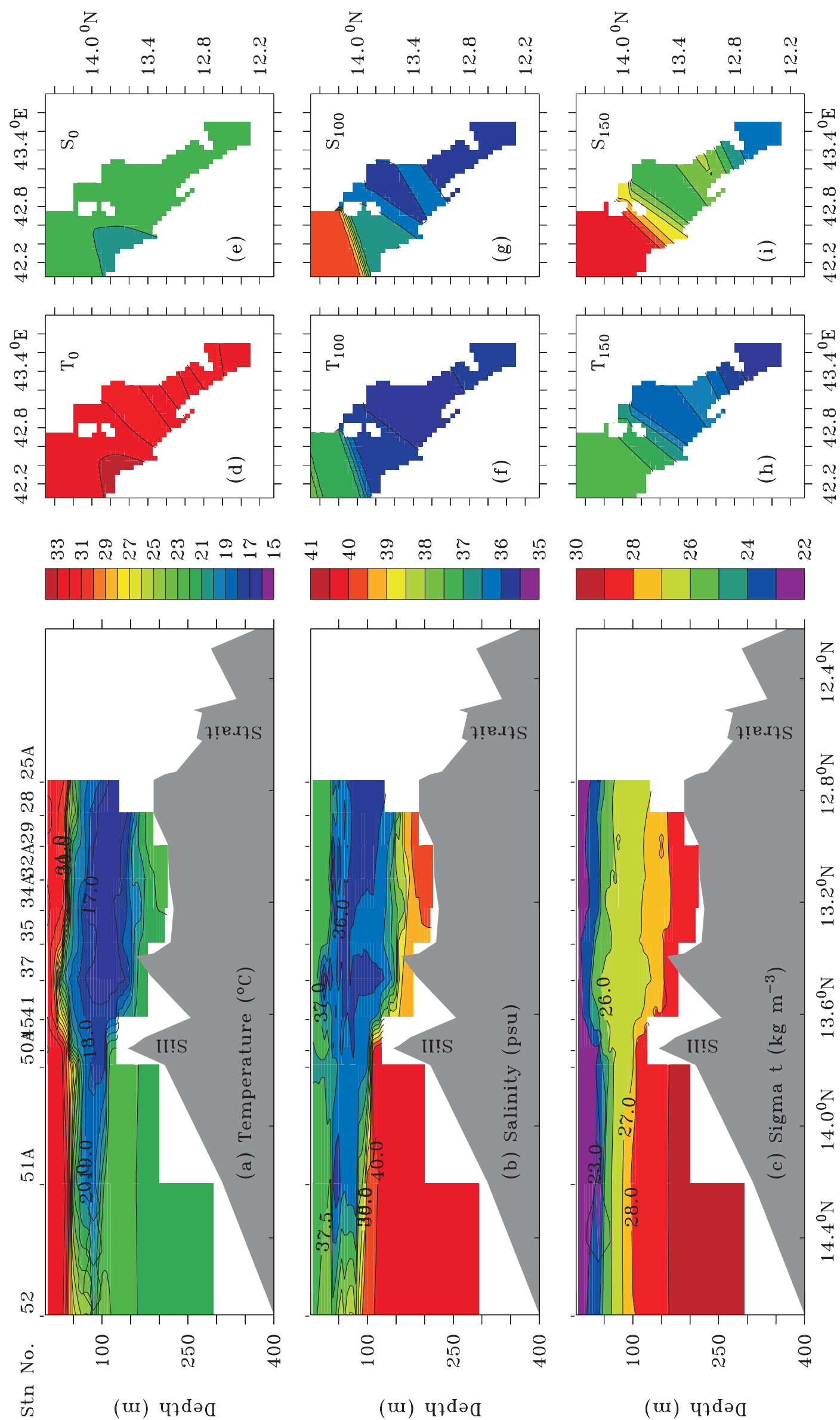

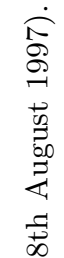
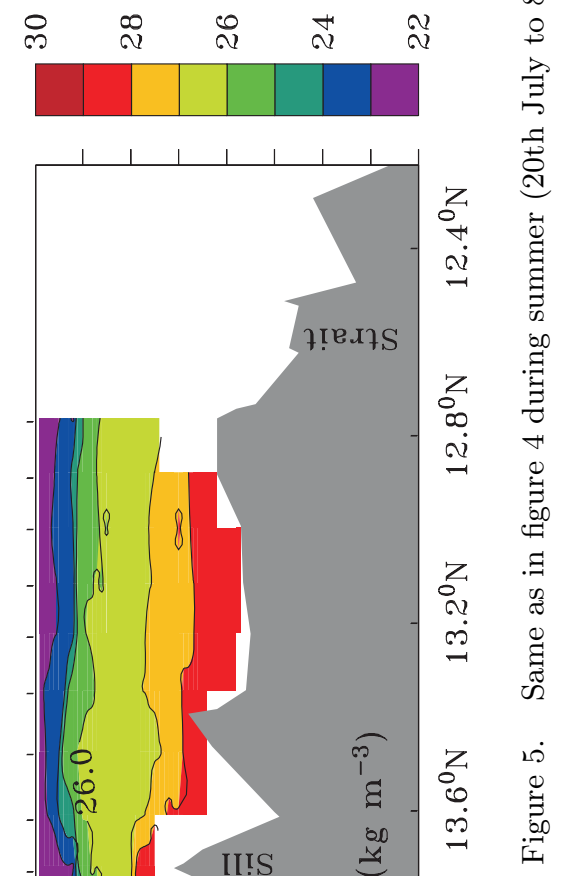

(u) чาdәฮ

(u) чา dәฮ 

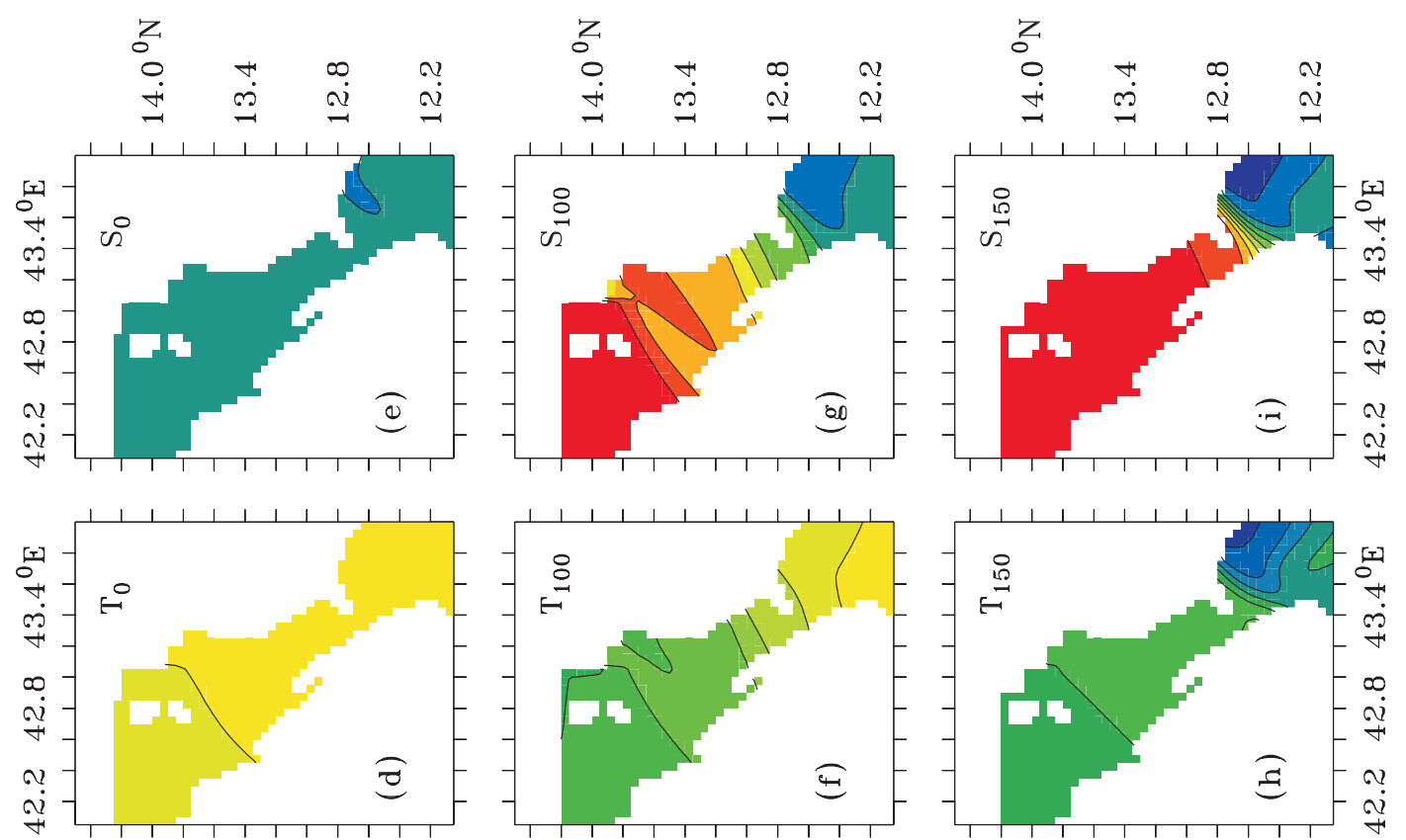

ติ
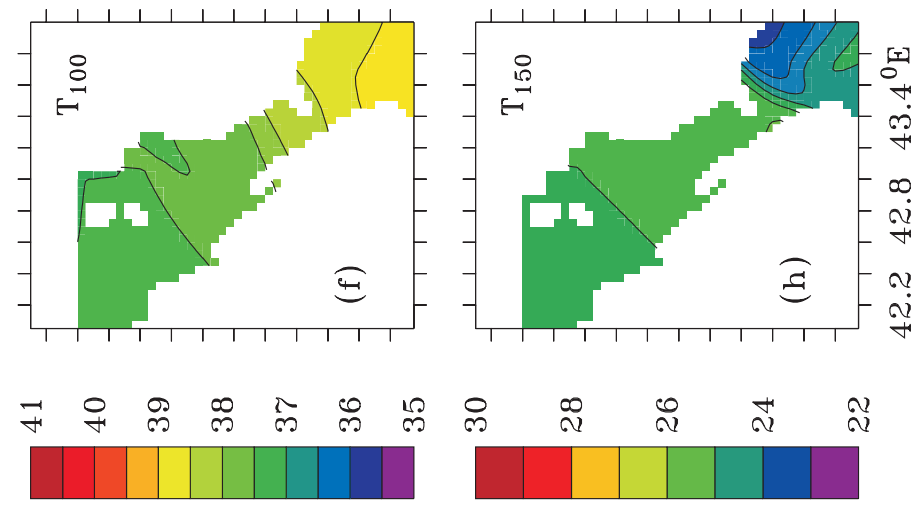

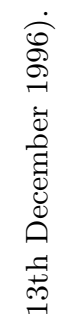
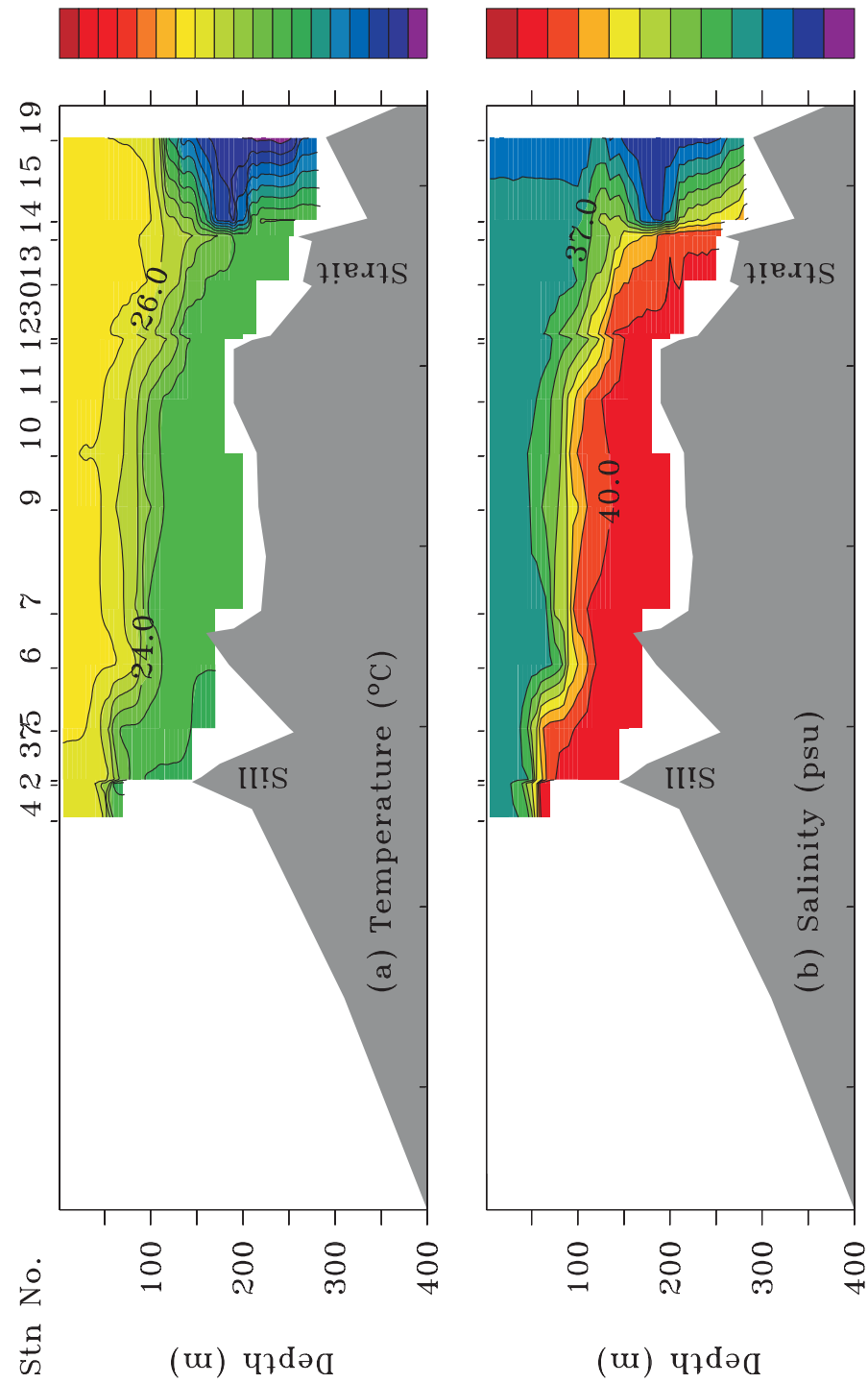

(w) чวdəฮ

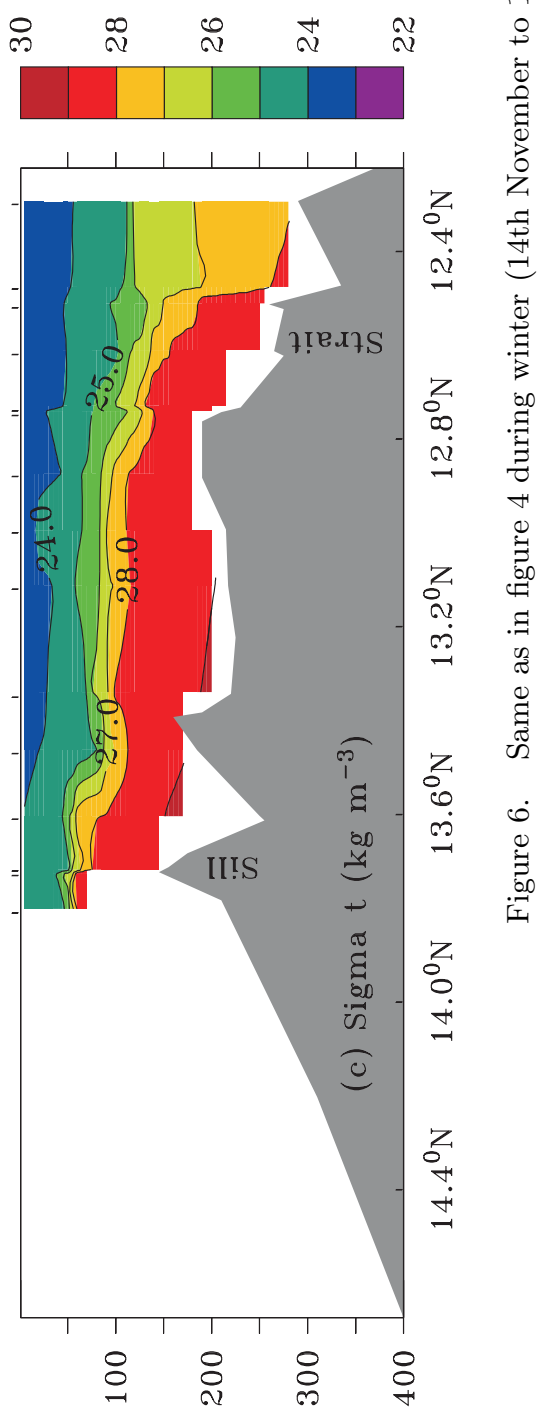

(w) чาdəฮ 
Hydrography in the Bab el Mandab region
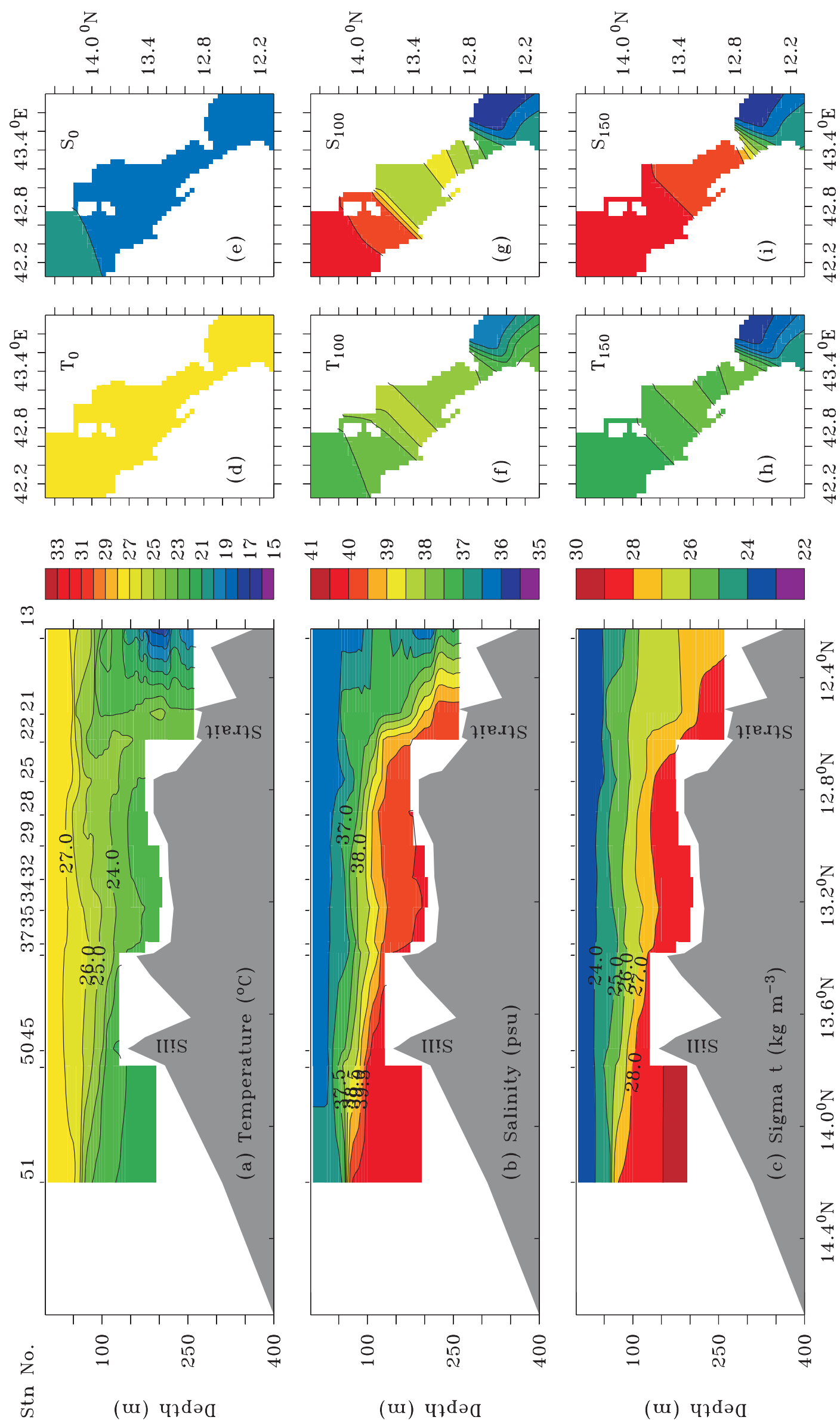

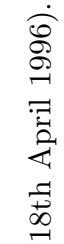
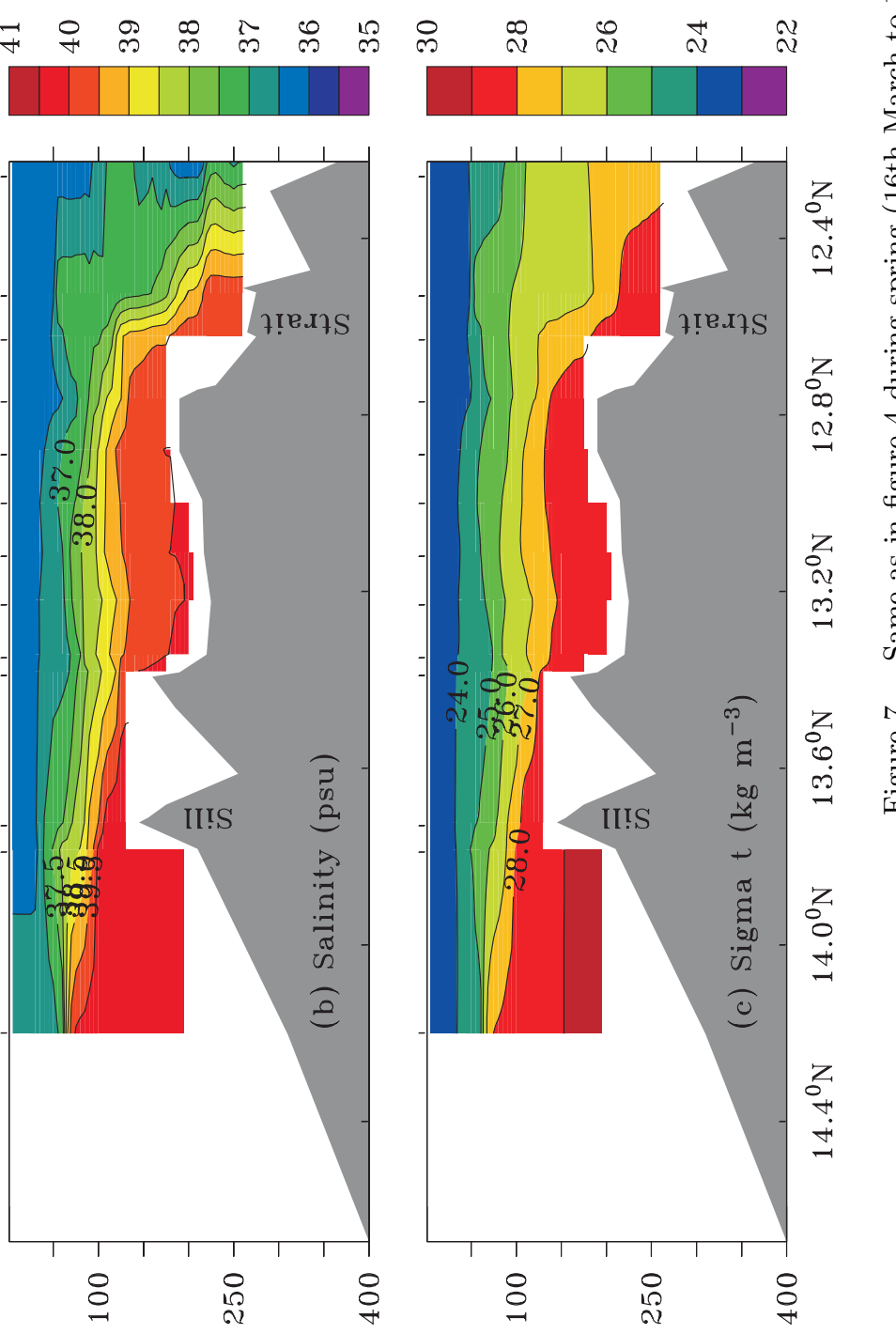

(ui) чา dәฮ
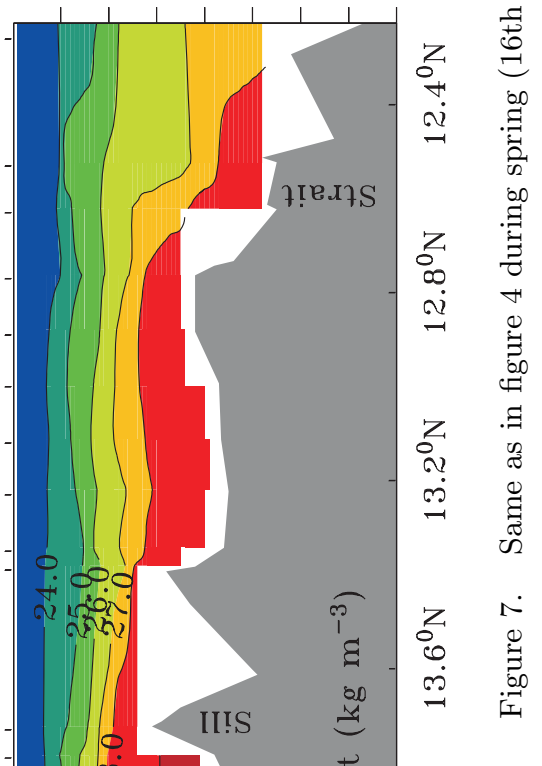
Using the direct measurements of currents MJ estimated these outflow volumes as $0.7 \mathrm{~Sv}$ and $0.05 \mathrm{~Sv}$ in winter and summer respectively. The surface layer which carried the GAW into the Red Sea was warmest during early summer $\left(\sim 29-30^{\circ} \mathrm{C}\right)$ and coolest during the winter $\left(\sim 27^{\circ} \mathrm{C}\right)$. Similarly, the salinity of this layer was lower $(\sim 36 \mathrm{psu})$ during early summer and higher during the winter $(\sim 37.0 \mathrm{psu})$. The RSW that flowed out during winter was warmer $\left(23.0-23.5^{\circ} \mathrm{C}\right)$ than that during summer or spring; it is coolest during summer $\left(\sim 22.0-22.5^{\circ} \mathrm{C}\right)$. This is consistent with the argument that most of the RSW forms near the surface in the north during winter and sinks (Maillard and Soliman 1986 and Cember 1988, Eschel et al 1994).

The temperature-salinity structure in the GA during all four seasons favours a three layer system (figures 4-7). Except during summer a tongue of GAW, in the intermediate level, stops south of the Bab el Mandab strait. Only during summer, when an outflow occurs in the surface layer, the intrusion of GAW manifests as a three layer system in the Bab el Mandab.

From the four hydrographic surveys, discussed here, it is clear that the reverse estuarine type situation prevailed during early summer, winter and spring and a three layer system prevailed during the summer. It is widely believed that the thermohaline circulation arising from the buoyancy forcing is responsible for the two layer system (Phillips 1966), and the reversal in the wind stress for the outflow in the thin upper layer (Maillard and Soliman 1986 and MJ). However, the findings from model studies (Sofianos and Johns 2002 and 2003) stress the importance of both thermohaline and wind forcing and their non-linear interactions in determining the seasonal variability. In summary, the hydrographic structure discussed here adds to the broken pieces already available from the earlier studies.

\section{Acknowledgements}

Professors S P Murray and W Johns provided the CTD data. Mr. Al Saafani is grateful for the support of the Faculty of Science, Sana'a University, Republic of Yemen and thanks the Director, NIO, for providing the opportunity to work in NIO. Ferret and GMT software are used for the preparation of figures. This is NIO contribution 3882 .

\section{References}

Bunkar A F, Charnock H, Goldsmith R A 1982 A note on the heat balance of the Mediterranean and Red Seas; J. Mar. Res. 40 73-84

Cember R P 1988 On the sources, formation, and circulation of Red Sea deep water; J. Geophys. Res. 93(C7) 81758191

Eschel G, Cane M A, Blumenthal M B 1994 Modes of subsurface, intermediate, and deep-water renewal in the Red Sea; J. Geophys. Res. 99 15941-15952

Maillard C 1974 Eaux intermediaires et formation d eau profonde en Mer Rouge, In: L'oceanographie physique de la Mer Rouge, Paris, 105-133 (Not referred in original).

Maillard C, Soliman G 1986 Hydrography of the Red Sea exchange with the Indian Ocean in summer; Oceanologica Acta $\mathbf{9} 1986$

Murray S P, Hecht A, Babcock A 1984 On the mean flow in the Tiran Strait in Winter; J. Mar. Res. 42 265-287

Murray S P and Johns W 1997 Direct observations of seasonal exchange through the Bab el Mandab strait; Geophys. Res. Lett. 24(21) 2557-2560

Neumann A C and McGill D 1962 Circulation of the Red Sea in the early summer; Deep-Sea Res. 8 223-235

Patzert W C 1972 Seasonal variations of structure and circulation in the Red Sea; Report of Hawaii Institute of Geophysics (HIG-72-13), 58pp.

Patzert W C 1974 Wind induced reversal in the Red Sea circulation; Deep Sea Res. 21 109-121, 1974

Phillips O M 1966 On turbulent convection currents and the circulation of the Red Sea; Deep-Sea Res. 13 $1148-1160$

Siedler G 1968 Schichtungs- und Bewegusverhältnisse am Südausgang des Roten Merres, "Meteor" Forschungsergebn, A(4): 1-76

Smeed D A 1997 Seasonal variation of the flow in the strait of Bab al Mandab; Oceanologica Acta 20 773-781

Smeed D A 2000 Hydraulic control of three-layer exchange flows: application to the Bab al Mandab; J. Phys. Oceangr. $302574-2588$

Sofianos S S, Johns W E, Murray S P 2002 Heat and freshwater budgets in the Red Sea from direct observations at Bab el Mandab; Deep-Sea Res. II 49 1323-1340

Sofianos S S, Johns W E 2002 An Ocean General Circulation Model (OGCM) investigation of the Red Sea circulation, 1. Exchange between the Red Sea and the Indian Ocean; J. Geophys. Res. 107 c11, 3196, doi: 10.1029/2001JC001184.

Sofianos S S, Johns W E 2003 An Ocean General Circulation Model (OGCM) investigation of the Red Sea circulation, 2. Three-dimensional circulation in the Red Sea; J. Geophys. Res. 108 No. C3, 3066, doi: 10.1029/ 2001JC001185.

Thompson E F 1939 Chemical and physical investigations, The exchange of water between the Red Sea and Gulf of Aden over the "sill"; John Murray Expedition, Scientific Report 23 83-103

Tragou E, Garrett C, Outerbridge R, Gilman G 1999 The heat and freshwater budgets of the Red Sea; J. Phys. Oceano. 29 2504-2522 